Jurnal Teknik Komputer AMIK BSI

Volume VI No.1 Januari 2020

P-ISSN 2442-2436, E-ISSN: 2550-0120

Akreditasi Ristekdikti, No: 21/E/KPT/2018

DOI: $10.31294 /$ jtk.v4i2

\title{
Rancang Bangun Sistem Informasi Biaya Perjalanan Dinas
}

\author{
Nurfarida ${ }^{1}$, Hilda Amalia ${ }^{2}$, Yunita ${ }^{3}$ \\ ${ }^{1,2,3}$ Universitas Bina Sarana Informatika \\ 1e-mail: keyza.gold@gmail.com \\ ${ }^{2}$ e-mail: hilda.ham@bsi.ac.id \\ 3 e-mail : yunita.ynt@bsi.ac.id

\begin{tabular}{ccc}
\hline Diterima & Direvisi & Disetujui \\
$14-10-2019$ & $02-01-2020$ & $30-01-2020$ \\
\hline
\end{tabular}

\begin{abstract}
Abstrak- Perjalanan bisnis adalah kegiatan rutin yang dilakukan oleh hampir semua lembaga pemerintah di Indonesia. Perjalanan bisnis membutuhkan biaya penganggaran khusus dan pada akhir kegiatan diperlukan laporan tentang penggunaan biaya atau anggaran yang disetujui. Masalah yang dihadapi dalam sistem biaya perjalanan resmi membutuhkan waktu yang cukup lama untuk menghasilkan laporan biaya perjalanan yang efektif dan efisien. Kesulitan dalam memantau perjalanan bisnis dilakukan baik dari segi biaya maupun waktu. Mencari data biaya perjalanan juga membutuhkan waktu lama, sehingga sulit untuk mengaudit biaya perjalanan resmi. Karena alasan ini, penting bagi semua lembaga atau perusahaan untuk membuat sistem informasi yang diketahui dapat menghasilkan laporan yang cepat, akurat, dan akurat serta dapat melakukan pemantauan kegiatan perjalanan resmi yang dilakukan. Hasil penelitian ini adalah sistem informasi untuk pembiayaan perjalanan dinas.
\end{abstract}

Kata Kunci : perjalanan resmi, biaya, sistem informasi

Abstract- Business travel is a routine activity carried out by almost all government agencies in Indonesia. Business travel requires special budgeting costs and at the end of the activity a report on the use of costs or an approved budget is required. Problems encountered in the official travel costs system take quite a long time to produce an effective and efficient travel expense report. Difficulties in monitoring business trips conducted both in terms of cost and time. Searching for travel cost data also takes a long time, making it difficult for auditing of official travel costs. For this reason it is important for all agencies or companies to create information systems that are known to be able to produce reports that are fast, accurate and accurate and able to carry out monitoring of official travel activities undertaken. The results of this study are an information system for official travel financing.

Keywords: official travel, cost, information system

\section{PENDAHULUAN}

Perjalanan dinas merupakan suatu tugas dan tanggung jawab yang rutin dilakukan oleh Pegawai Negeri Sipil dengan tujuan menghadiri seminar, diklat, tender dan kegiatan lainnya (Haryanti, Witanti, \& Hadiana, 2016). Kegiatan Perjalanan dinas ini memerlukan anggaran atau biaya yang harus dikeluarkan oleh instansi pemerintah.

Perjalanan dinas merupakan kegiatan yang menggunakan biaya yang besar untuk itu harus dikelola dengan sebaik mungkin sehingga tercapai efisiensi penggunaan dana dan sumber daya manusia. Namun pada prakteknya banyak sekali bentuk penyalahgunaan dari anggaran atau biaya perjalan dinas yang dilakukan oleh pegawai. Penyelewengan anggaran ini disebabkan oleh manajemen perjalanan dinas yang masih semberawut sehingga pelaksanaan dinas menjadi tidak efisien dan tidak efektif (Nurcahyo \&
Agustina, 2012). Untuk itu diperlukan suatu sistem informasi yang sehingga dapat meminimalkan penyalahgunaan dana serta mampu mengefektifkan perjalanan dinas yang dilakukan.

Informasi merupakan hal yang sangat penting, maka diperlukan teknologi untuk mengolah informasi tersebut, ketidakakurat data yang disampaikan kepada pimpinan dapat berakibat fatal bagi kemajuan suatu instansi (Mulyati \& Fajarita, 2018) Penggunaan sistem informasi diperlukan untuk memudahkan karyawan dalam melaporkan kegiatan dan memudahkan dalam proses pelaporan keuangan (Rachmawati, Retnasari, \& Sunarto, 2018). Melalui sistem informasi dapat membantu instansi untuk mendapatkan solusi terbaik untuk mengelola informasi dan sumber daya untuk mencapai produktifitas, keakuratan, efektivitas dan efisiensi sesuai dengan target kerja yang telah ditetapkan. Sistem informasi mampu meningkatkan kecepatan 
dan mengurangi kesalahan yang dilakukan oleh manusia sehingga dapat mencapai efisiensi kerja (Mamase, 2016, p. 2016)Sistem informasi merupakan suatu hal yang harus dimiliki oleh setiap organisasi untuk menunjang kegiatan manajerial dan kinerja dalam segala bidang (Silvana, Fajrin, \& Danton, 2015)

Kendala lain dalam perjalanan dinas adalah proses pembuatan surat perintah pelaksana tugas yang terlalu lama karena distribusi dan verifikasi surat yang harus disetujui dan ditanda tangani oleh beberapa pimpinan (Prasetyaningrum \& Juanita, 2018). Hal ini makin bertambah memakan waktu karena jumlah perjalanan dinas yang makin bertambah disetiap instansi pemerintahan.

Berdasarkan permasalahan tersebut maka untuk itu dibangun suatu sistem informasi pembiayaan perjalanan dinas.

\section{METODE PENELITIAN}

Untuk menghasilkan suatu hasil yakni berubah suatu sistem informasi pembiayaan perjalanan dinas, diperlukan beberapa tahapan penelitian. Tahapan penelitian dalam penelitian ini disajikan dalam Gambar 1

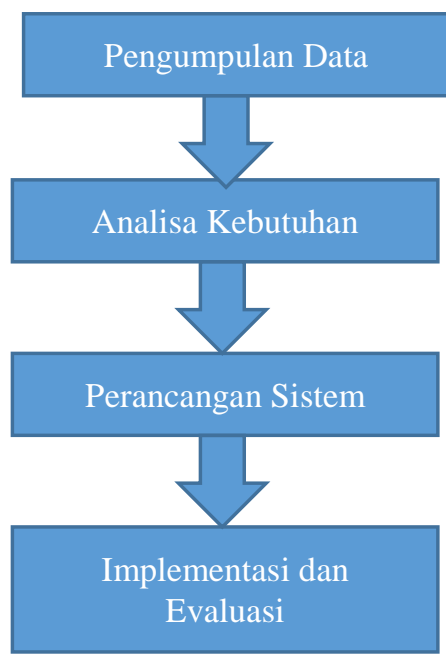

Sumber : penulis (2019)

Gambar 1 Tahapan penelitian

Pada gambar 1 disajikan tahapan peneliltian yang ditempuh melalui empat langkah. Tahapan pertama adalah pengumpulan data. Dalam pengumpulan data dilakukan beberapa cara. Teknik pertama adalah dilakukan Tanya jawab atau wawancara. Wawancara dilakukan oleh orang-orang yang terlibat langsung dengan sistem perjalanan dinas. Teknik pengumpulan data dilakukan dengan cara melakukan wawancara dengan user, pimpinan dan staf-staf instansi pemerintah. Dari teknik wawancara diperoleh masalah yang dihadapi oleh badan usaha serta mendapatkan gambaran mengenai sistem informasi yang akan dibangun (Muthia, Amalia, Puspita, \& Lestari, 2019). Teknik berikutnya adalah dilakukan pengumpulan data dengan cara observasi yaitu dilakukan pengamatan langsung di tempat terjadinya perjalanan dinas yakni diinstansi pemerintahan. Sehingga diperoleh datadata yang dibutuhkan untuk membangun sistem yang dapat menyelesaikan masalah pada bidang perjalanan dinas instansi pemerintah. Dari obsevasi diperoleh mengenai gambaran sistem yang berjalan, analisa dilakukan dengan melakukan analisa dokumen (Muthia, Amalia, Puspita, \& Lestari, 2019). Tahapan kedua yakni Perancangan sistem, dalam tahapan ini dilakukan design sistem dengan menggunakan diagram UML(Unifed Modelling Language), design table dengan ERD(Entity Relationship Diagram), pembuatan coding program dengan menggunakan bahasa pemograman web yaitu bahasa pemograman php serta memanfaatkan bahasa Mysql. Tahapan terakhir adalah implementasi dan evaluasi, dalam tahapan ini dilakukan uji coba sistem yang sudah ditelah dibuat dengan menggunakan blackbox testing. Black box testing dilakukan untuk memastikan keluaran sistem sesuai dengan yang diinginkan (Muthia, Amalia, Puspita, \& Lestari, 2019)..

\section{HASIL DAN PEMBAHASAN}

Analisa kebutuhan sistem

Kebutuhan sistem merupakan layanan dalam sebuah aplikasi yang harus disediakan, serta gambaran proses dari reaksi sistem terhadap masukan sistem.

Berikut yang akan dikerjakan oleh sistem adalah: A. Prosedur penginputan data pegawai Sistem melakukan proses penyimpanan data pegawai didalam database pegawai setelah data tersebut diinput serta memberikan informasi tentang penjelasan data pegawai yang dicari entitas.

B. Prosedur penerbitan Surat Tugas

Pada penginputan surat tugas dimana data diambil dari tabel database pegawai, sistem akan memproses data pegawai dan kemudian menyimpan didalam tabel database surat tugas. Lalu sistem melakukan proses cetak dan menghasilkan form Surat Tugas.

C. Prosedur Penerbitan SPPD

Pada penginputan SPPD dimana data yang diinput diperoleh dari tabel database Surat Tugas, lalu sistem akan memproses dan menyimpan kedalam tabel database SPPD, kemudian dari database SPPD dilakukan proses cetak dan menghasilkan form SPPD.

D. Prosedur Penerbitan Biaya SPPD

Ketika entitas admin menginputkan biaya SPPD, sistem akan memproses dan menyimpan ke dalam tabel database biaya SPPD dimana data diperoleh dari tabel database SPPD dan database Surat Tugas yang kemudian nanti akan dilakukan proses cetak dan menghasilkan kwitansi biaya SPPD.

E. Prosedur Realisasi Biaya 
Untuk proses realisasi biaya SPPD data diambil dari tabel database SPPD dan tabel database biaya SPPD. Sistem memproses dan menyimpan di dalam database realisasi biaya. Kemudian dilakukan proses cetak sehingga menghasilkan laporan rincian realisasi biaya. Dalam hal ini yang melakukan input data adalah entitas pegawai. Pada entitas admin hanya dapat memverifikasi laporan realisasi biaya.

Analisa Kebutuhan Software

Dalam aplikasi sistem informasi biaya perjalanan dinas terdapat dua pengguna yang dapat saling berinteraksi dalam lingkungan sistem, yaitu: bagian admin dan bagian pegawai. Kedua pengguna tersebut memiliki karakteristik interaksi dengan sistem yang berbeda-beda dan memiliki kebutuhan informasi yang berbeda, diantaranya sebagai berikut

A. Analisa Kebutuhan Admin :

A1. Admin dapat melakukan login

A2. Admin dapat mengelola data pengguna

A3. Admin dapat mengelola pegawai

A4. Admin dapat mengelola Surat Tugas (ST)

A5. Admin dapat mengelola SPPD

A6. Admin dapat mengelola Biaya SPPD

A7. Memverifikasi data realisasi biaya

B. Analisa Kebutuhan Pegawai:

B1. Pegawai dapat melakukan login

B2. Pegawai dapat menginput data realisasi biaya

Use Case Diagram Admin

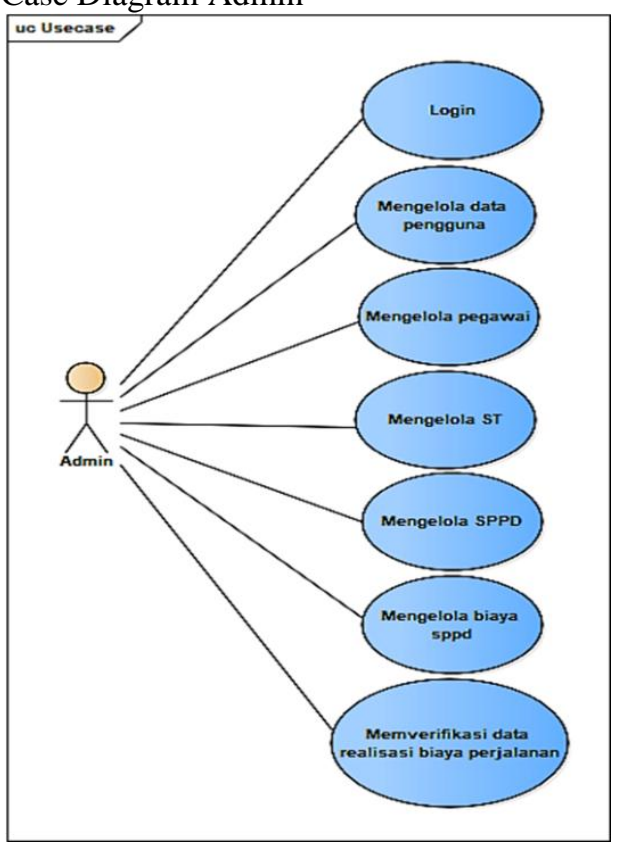

Sumber : penulis (2019)

Gambar 3 Use Case Diagram Admin
Dalam mendesign sistem digunakan diagram UML yang pertama yaitu design useuase. Usecase merupakan diagram yang menjelaskan apa yang bisa dilakukan user terhadap sistem. Gambar 3 merupakan usecase diagram admin. Pada gambar 3 terdapat satu actor yakni admin yang dapat melakukan usecase login, mengelola data pengguna, mengelola data pegawai, mengelola ST (Surat Tugas), Mengelola SPPD, mengelola biaya SPPD, menverifikasi data realisasi perjalan.

Use case pegawai

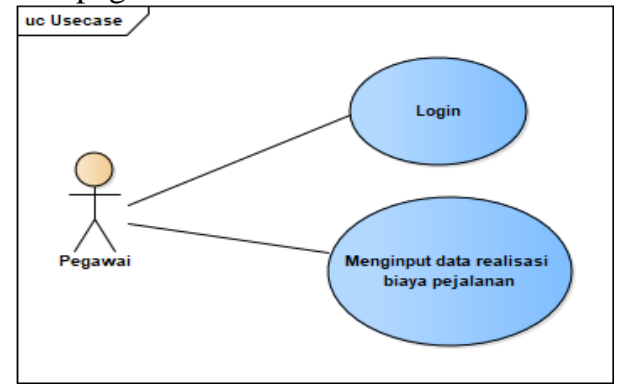

Sumber : penulis (2019)

Gambar 4 Use Case Diagram Pegawai

Gambar 4 merupakan use case Pegawai yang akan menjalankan kegiatan perjalan dinas. Use case yang dapat dilakukan adalah login dan menginput data realisai biaya perjalanan.

Activity Diagram

Diagram berikutnya yang digunakan adalah activity diagram. Activity diagram digunakan untuk menjabarkan kegiatan yang dilakukan dalam satu use case.

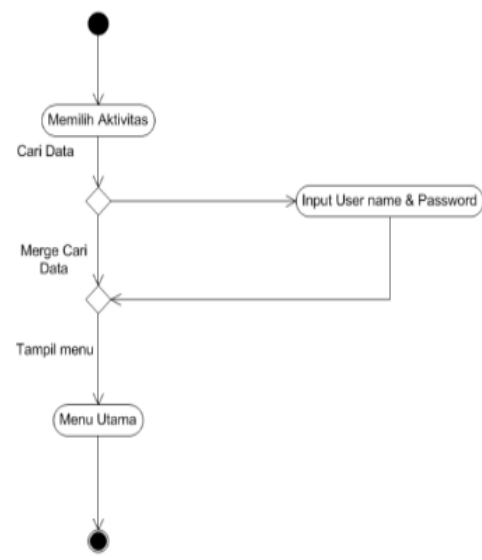

Sumber : penulis (2019)

\section{Gambar 5 Activity Diagram Login}

Gambar 5 menjelaskan mengenai aktivitas yang terdapat dalam use case login, kegiatan dimulai saat user memilih aktivitas login, menginput username dan password kemudian ke aktivitas menu utama. 
Activity Diagram mengelola data pengguna

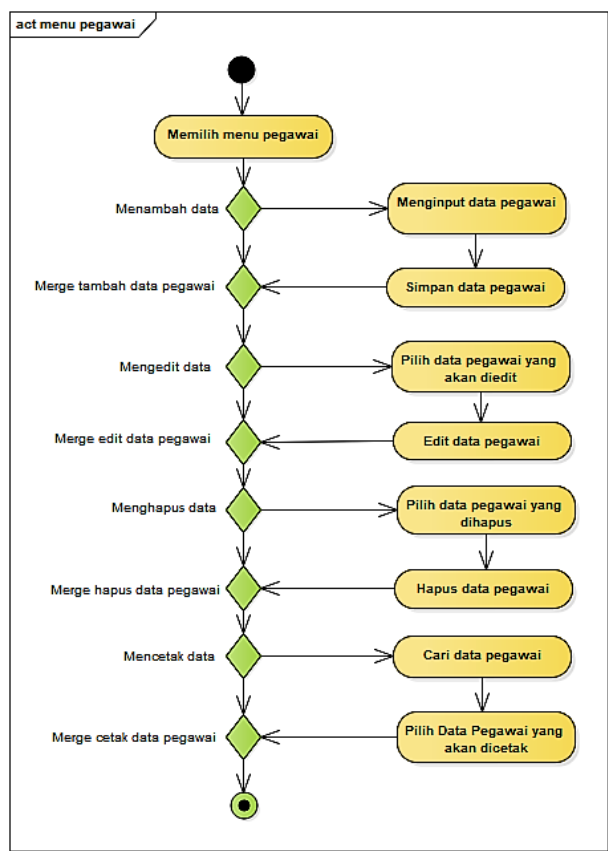

Sumber : penulis (2019)

Gambar 6 Activity Diagram mengelola data pegawai

Gambar 6 merupakan activity diagram use case mengelola data pegawai, aktivitas dimulai dari menu pegawai, menginput data pegawai, simpan data pegawai, pilih data pegawiyang akan diedit, edit data pegawai, memilihi data pegawai yang akan dihapus, hapus data pegwai, melakukan mencarian data pegawai, mencetak data pegawai yang akan dicetak.

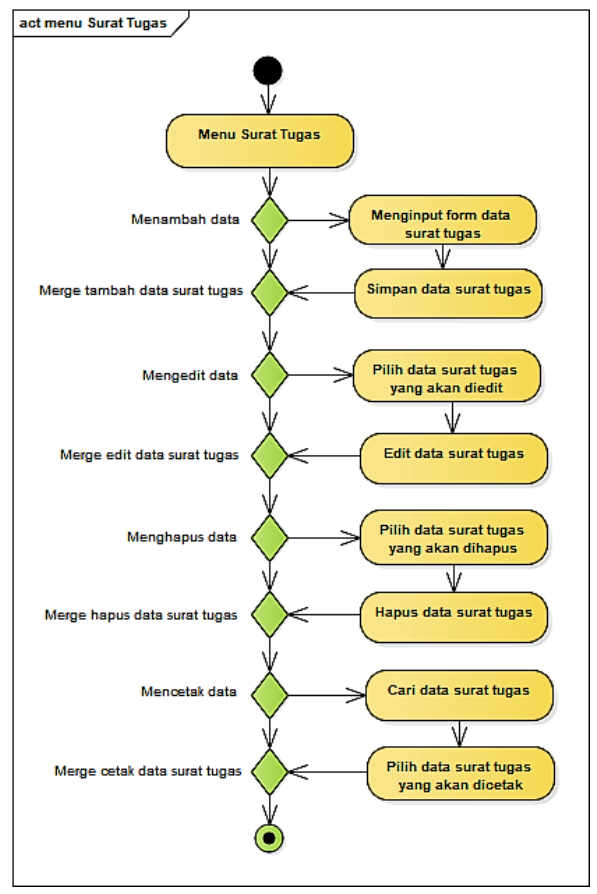

Sumber : penulis (2019)
Gambar 7 activity diagram Surat Tugas

Activity diagram surat tugas merupakan aktivitas yang dapat dilakukan dalam usecase mengelola data ST(Surat Tugas). Kegiatan yang dilakukan dimulai dari memilih mengelola ST, kemudidan menambah data, menginput data Surat Tugas, menyimpan data surat tugas, mengedit data, memilih surat tugas yang akan diedit, mengedit data surat tugas, menghapus data, memilih data surat tugas yang akan dihapus, menghapus data surat tugas, mencetak data, mencari data surat tugas yang akan dicetak, mencetak surat tugas.

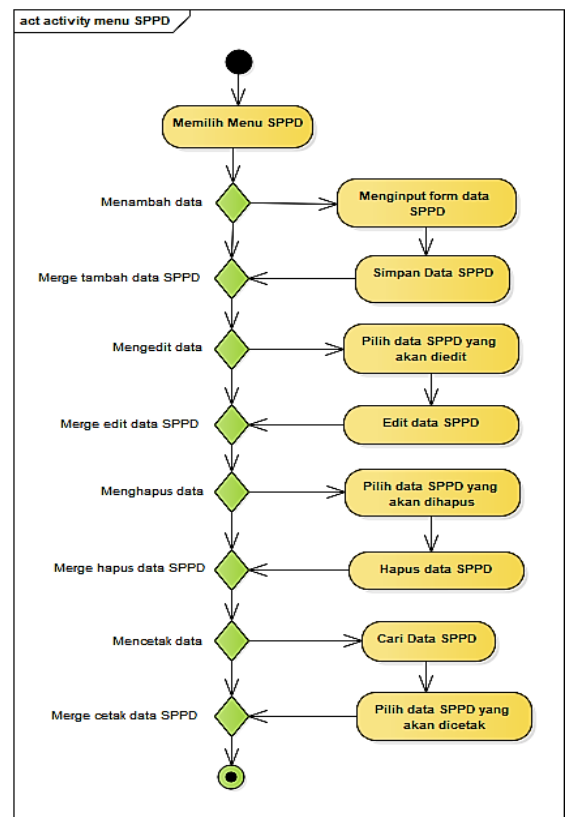

Sumber : penulis (2019)

Gambar 8 Activity Diagram mengelola data SPPD

Gambar 8 merupakan activity diagram menu SPPD rincian aktivitas dari use case mengelola SPPD. Aktivitas pertama adalah memilih menu SPPD, menambah data, menginput data SPPD, mengedit data kemudian memilih data SPPD yang akan diedit, edit data SPPD, menghapus data, memilih data SPPD yang akan dihapus, hapus data SPPD, m,mencetak data, car data SPPD, memilih data SPPD yang akan dicetak, kegaitan selesai. 


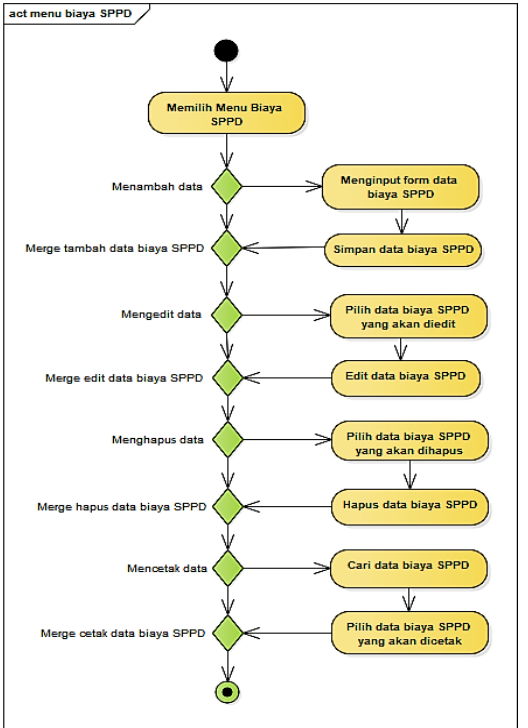

Sumber : penulis (2019)

\section{Gambar 9 Activity Diagram Biaya SPPD}

Gambar 9 merupakan activity diagram dari use case mengelolah biaya SPPD, kegaitan dimulai dari memilih aktivitas biaya SPPD, menambah data, menginput data, mengedit data, memilih data biaya SPPD, edit data SPPD, menghapus data, memilih data biaya SPPD yang akan dihapus, hapus data biaya SPPD, mencetak data, cari data biaya SPPD, memilih data SPPD yang akan dicetak. Kegaitan selesai.

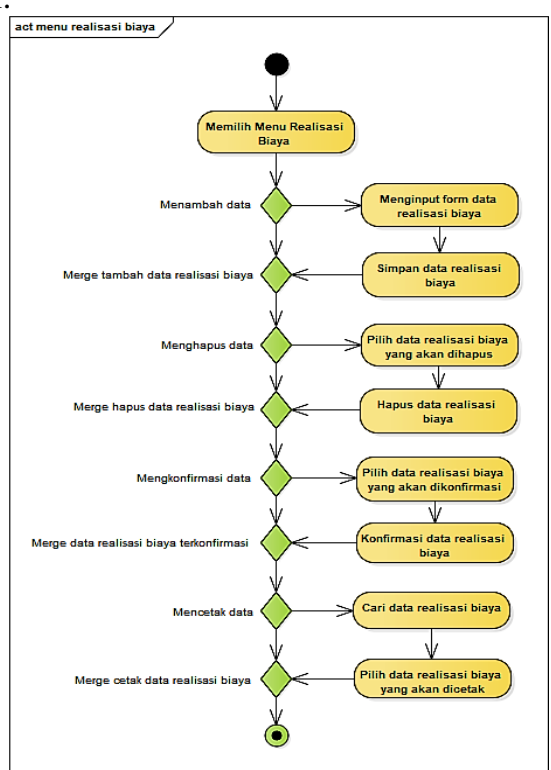

Sumber : penulis (2019)

Gambar 10 Activity Diagram Realisasi Biaya

pegawai melakukan penginputan data dengan memilih menu realisasi biaya lalu sistem mengarahkan pada data realisasi biaya yang didalamnya terdapat function tambah dan cetak yang kemudian sistem memproses semua function yang Nurfarida, Hilda Amalia,Yunita sudah diinput pegawai. Sedangkan admin hanya melakukan konfirmasi dan menghapus data realisasi biaya.

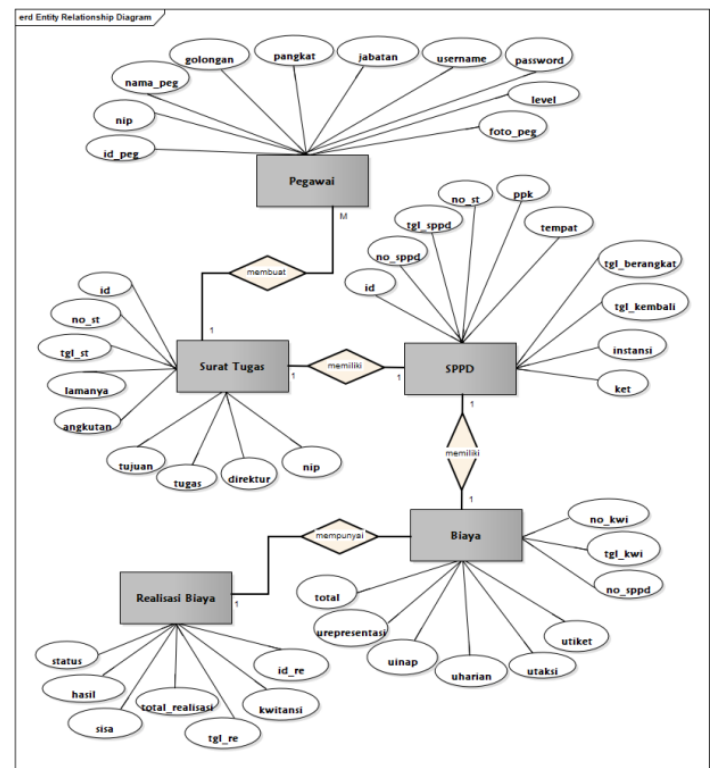

Sumber : penulis (2019)

Gambar 11 Entity Relationship Diagram

Gambar 11 mengambarkan hubungan antar entitas yang dimiliki dalam sistem informati pembiayaan perjalanan dinas. Entitas yang terlibat berjumlah lima entitas, yaitu pegawai, surat tugas, SPPD, Biaya dan realisasi biaya. Entity pegawai berelasi dengan Surat Tugas, entity Surat Tugas berelasi engan SPPD, entitiy SPPD berelasi dengan Biaya, dan entitias biaya berelasi dengan Realisasi Biaya. Setiap entity memilih atibut yang melekat pada entitas masing-masing.

User Interface

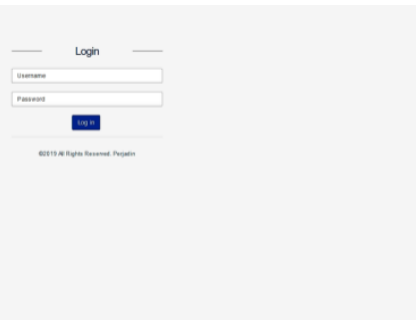

Sumber : penulis (2019)

\section{Gambar 12 User interface Halaman Login}

Gambar 12 merupakan user interface halam login, terdiri dari dua textbox untuk menginput username dan password dan satu button untuk login. Masukan username dan password kemudian klik login jika data cocok dengan database maka akan masuk ke menu utama. 


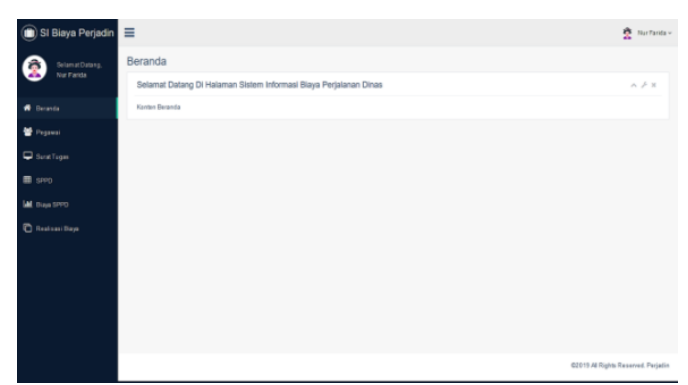

Sumber : penulis (2019)

Gambar 13 Menu utama Halama Admin

Gambar 13 merupakan user interface halaman beranda Admin. Admin dapat melakukuan Halaman beranda ini berfungsi sebagai halaman untuk mengelola data pengguna, data pegawai, Surat Tugas, SPPD, Biaya SPPD dan Realisasi biaya

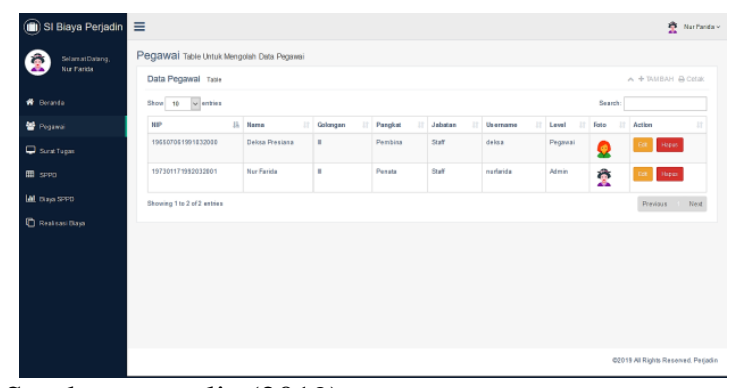

Sumber : penulis (2019)

Gambar 14 Halaman Data Pegawai

Gambar 14 merupakan user interface halaman data pegawai. Halaman ini berfungsi sebagai halaman untuk menambah, mengedit, menghapus, mencari dan mencetak data pegawai.

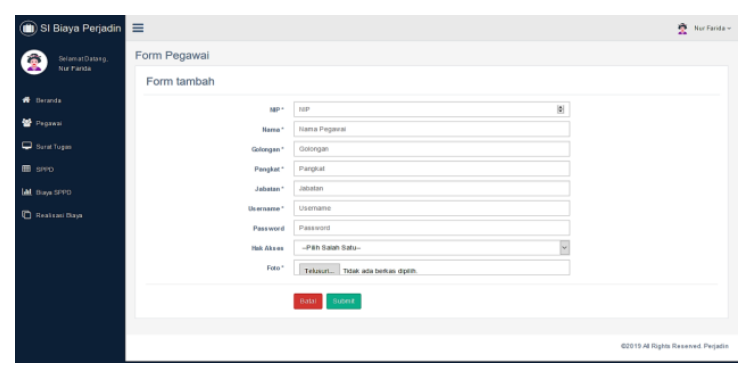

Sumber : penulis (2019)

\section{Gambar 15 Form Tambah Data Pegawai}

Gambar 15 merupakan user interface form tambah data pegawai. Halaman ini berfungsi sebagai halaman untuk menginput data pegawai. Setelah diinput kemudian data disimpan

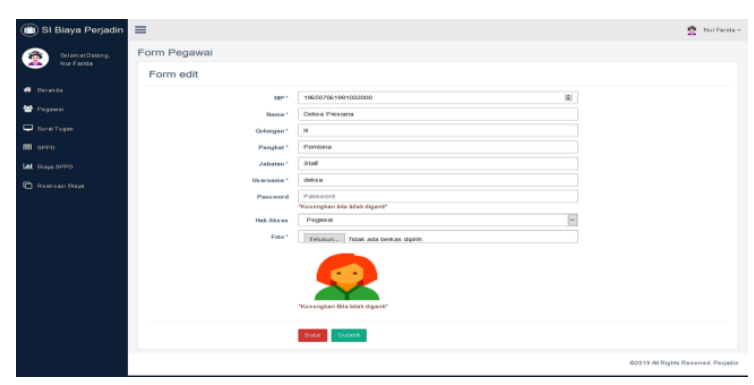

Sumber : penulis (2019)

\section{Gambar 16 Form Edit Data Pegawai}

Gambar 16 merupakan user interface edit data pegawai. Pada halaman ini berfungsi sebagai halaman untuk mengedit data pegawai. Setelah diedit kemudian data disimpan

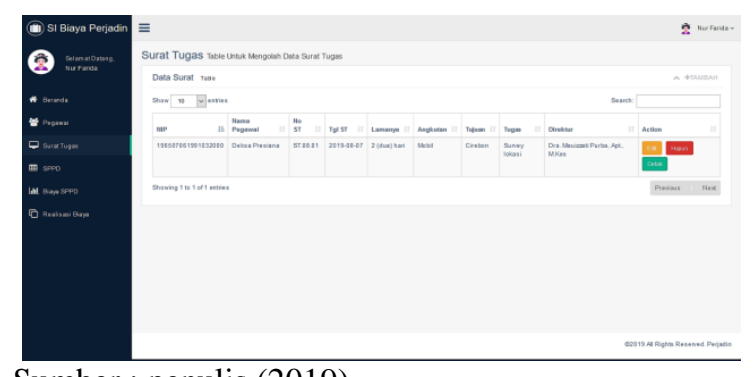

Sumber : penulis (2019)

\section{Gambar 17 Halaman Surat Tugas}

Gambar 17 user interface halaman surat tugas. Pada halaman Surat Tugas ini sebagai bukti penugasanpegawai yang ditugaskan untuk melakukan perjalanan dinas

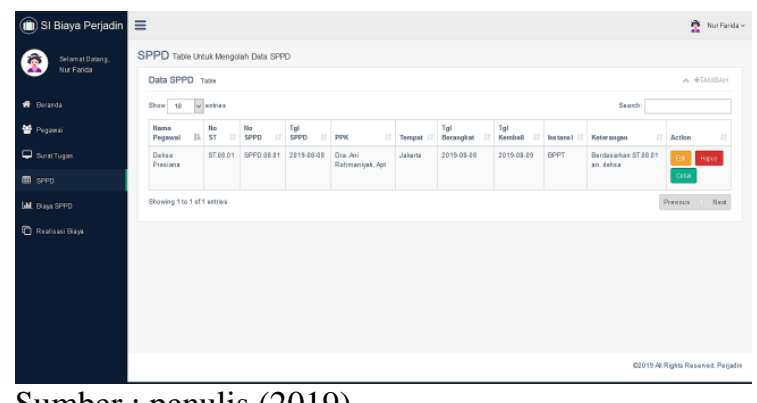

Sumber : penulis (2019)

\section{Gambar 18 Halaman SPPD}

Gambar 18 user interface halaman SPPD. Pada halaman ini untuk digunakan admin untuk menginput data pegawai yang akan melakukan perjalanan dinas. 


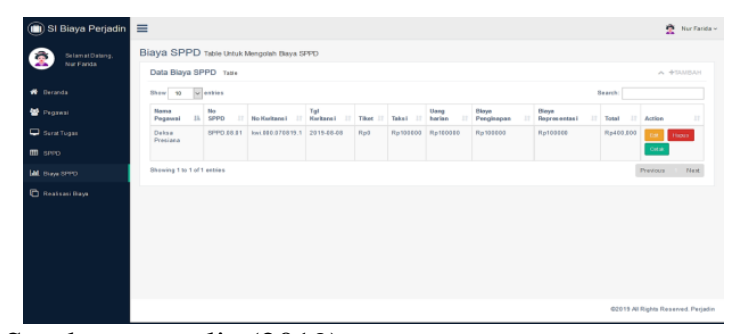

Sumber : penulis (2019)

Gambar 20 Halaman Biaya SPPD

Gambar 20 User interface Biaya SPPD. Pada halaman ini admin melakukan input data biaya SPPD untuk pegawai yang melakukan perjalanan dinas.

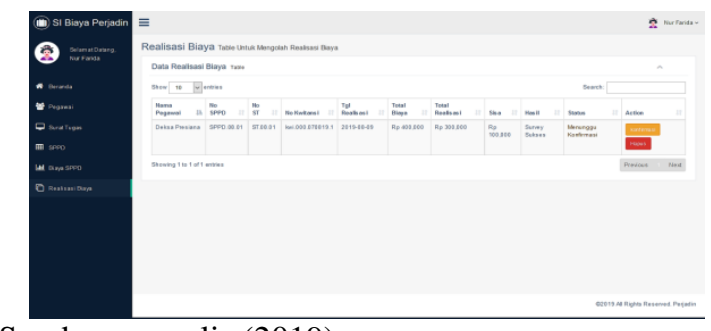

Sumber : penulis (2019)

Gambar 15 Halaman Realisasi Biaya-menunggu konfirmasi

Gambar 15 merupakan halaman realisasi biaya yang menunggu konfirmasi. Pada halaman ini admin hanya dapat melakukan konfirmasi terhadap hasil realisasi biaya yang telah dilakukan oleh pegawai. Dan admin juga dapat melakukan hapus data jika data tidak diperlukan.

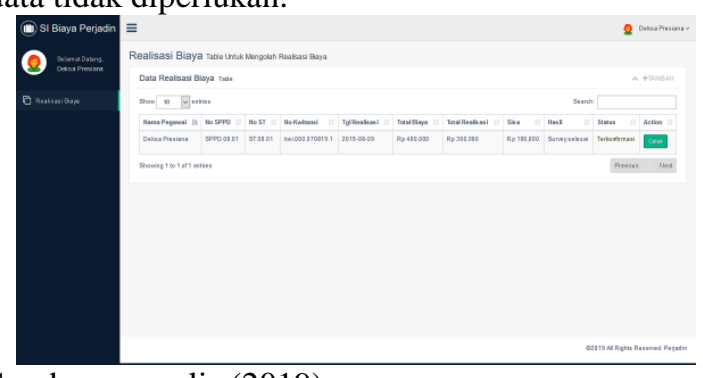

Sumber : penulis (2019)

Gambar 16 Halaman Realisasi Biaya-terkonfirmasi

Gambar 16 merupakan halaman realisasi biaya yang sudah di setujui oleh admin. Pada halaman ini realisasi biaya yang sudah terkonfirmasi, pegawai dapat melakukan tambah data dan mencetak data setelah data sudah dikonfirmasi oleh admin Blackbox Testing

Tabel 1Blackbox Testing

\begin{tabular}{cccccc}
\hline $\mathrm{N}$ & Skenario & Test & Hasil yang & Hasil & Keter \\
o & Pengujian & Case & diharapka & Penguji & anga \\
\hline
\end{tabular}

\begin{tabular}{|c|c|c|c|c|c|}
\hline & & & $\mathrm{n}$ & an & $\mathrm{n}$ \\
\hline 1 & $\begin{array}{l}\text { Mengoson } \\
\text { gkan data } \\
\text { username } \\
\text { dan } \\
\text { password } \\
\text { lalu klik } \\
\text { 'Login' }\end{array}$ & $\begin{array}{l}\text { Usern } \\
\text { ame: } \\
\text { (koson } \\
\text { g) } \\
\text { Passw } \\
\text { ord: } \\
\text { (koson } \\
\text { g) }\end{array}$ & $\begin{array}{l}\text { Sistem } \\
\text { akan } \\
\text { menolak } \\
\text { akses } \\
\text { login dan } \\
\text { akan } \\
\text { muncul } \\
\text { dialog "Isi } \\
\text { isian ini”" } \\
\end{array}$ & $\begin{array}{l}\text { Sesuai } \\
\text { harapan }\end{array}$ & Valid \\
\hline 2 & $\begin{array}{l}\text { Mengoson } \\
\text { gkan data } \\
\text { username } \\
\text { dan } \\
\text { mengisi } \\
\text { data password, } \\
\text { lalu klik } \\
\text { 'Login' }\end{array}$ & $\begin{array}{l}\text { Usern } \\
\text { ame: } \\
\text { (koson } \\
\text { g) } \\
\text { Passw } \\
\text { ord: } \\
\text { (isi }\end{array}$ & $\begin{array}{l}\text { Sistem } \\
\text { akan } \\
\text { menolak } \\
\text { akses } \\
\text { login dan } \\
\text { akan } \\
\text { muncul } \\
\text { dialog "Isi } \\
\text { isian ini"" } \\
\end{array}$ & $\begin{array}{l}\text { Sesuai } \\
\text { harapan }\end{array}$ & Valid \\
\hline 3 & $\begin{array}{l}\text { Mengisi } \\
\text { data } \\
\text { username } \\
\text { benar } \\
\text { password } \\
\text { salah, lalu } \\
\text { klik } \\
\text { 'Login' }\end{array}$ & $\begin{array}{l}\text { Usern } \\
\text { ame: } \\
\text { (benar } \\
\text { ) } \\
\text { Passw } \\
\text { ord: } \\
\text { (salah) }\end{array}$ & $\begin{array}{l}\text { Sistem } \\
\text { akan } \\
\text { menolak } \\
\text { akses } \\
\text { login dan } \\
\text { akan } \\
\text { muncul } \\
\text { dialog } \\
\text { "Usernam } \\
\text { e Atau } \\
\text { Password } \\
\text { Salah" }\end{array}$ & $\begin{array}{l}\text { Sesuai } \\
\text { harapan }\end{array}$ & Valid \\
\hline 4 & $\begin{array}{l}\text { Mengisi } \\
\text { data } \\
\text { username } \\
\text { salah } \\
\text { password } \\
\text { benar, lalu } \\
\text { klik } \\
\text { 'Login' }\end{array}$ & $\begin{array}{l}\text { Usern } \\
\text { ame: } \\
\text { (salah) } \\
\text { Passw } \\
\text { ord: } \\
\text { (benar } \\
\text { ) }\end{array}$ & $\begin{array}{l}\text { Sistem } \\
\text { akan } \\
\text { menolak } \\
\text { akses } \\
\text { login dan } \\
\text { akan } \\
\text { muncul } \\
\text { dialog } \\
\text { "Usernam } \\
\text { e Atau } \\
\text { Password } \\
\text { Salah" }\end{array}$ & $\begin{array}{l}\text { Sesuai } \\
\text { harapan }\end{array}$ & Valid \\
\hline 5 & $\begin{array}{l}\text { Mengisi } \\
\text { data } \\
\text { Username } \\
\text { dan } \\
\text { Password } \\
\text { dengan } \\
\text { benar, lalu } \\
\text { klik } \\
\text { 'Login' }\end{array}$ & $\begin{array}{l}\text { Usern } \\
\text { ame: } \\
\text { (Isi) } \\
\text { Passw } \\
\text { ord: } \\
\text { (Isi) }\end{array}$ & $\begin{array}{l}\text { Sistem } \\
\text { akan } \\
\text { menerima } \\
\text { akses } \\
\text { login dan } \\
\text { menampil } \\
\text { kan } \\
\text { halaman } \\
\text { Beranda }\end{array}$ & $\begin{array}{l}\text { Sesuai } \\
\text { harapan }\end{array}$ & Valid \\
\hline
\end{tabular}

Sumber : penulis (2019)

\section{KESIMPULAN}

Penelitian yang telah penulis lakukan dan diuraikan pada bab sebelumnya dan juga dalam pembahasan yang menghasilkan beberapa kesimpulan antara lain: Sistem Informasi Biaya Perjalanan Dinas Pada Instansi Pemerintah telah melalui tahap pengujian dan sesuai dengan kebutuhan pengguna. Sistem Informasi Biaya Perjalanan Dinas Pada Instansi Pemerintah menyediakan fitur tambah, ubah, dan hapus data yang berhubungan dengan pembuatan Surat Tugas, SPPD, Biaya, dan Realisasi Biaya di dalam halaman admin. Sistem Informasi Biaya 
Perjalanan Dinas Pada Instansi Pemerintah juga menampilkan keluaran Surat Tugas, SPPD, Biaya, dan Realisasi Biaya dalam bentuk halaman yang siap cetak dan disimpan dalam bentuk format .pdf. Selain itu dengan disediakannya fitur pencarian di dalam halaman admin akan memudahkan pegawai dalam mencari data. Pembuatan Sistem Informasi Biaya Perjalanan Dinas Pada Instansi Pemerintah ini dapat membantu menyelesaikan masalah yang ada dalam melakukan peningkatan efektifitas pelayanan perjalanan dinas. Dengan adanya Sistem Informasi ini perjalanan dinas pegawai dapat terkontrol dengan baik. Dengan sistem informasi perjalanan dinas seperti ini dapat mengubah kinerja Instansi Pemerintah menjadi lebih baik dan lebih profesional dalam aktivitasnya.

\section{REFERENSI}

Haryanti, N., Witanti, W., \& Hadiana, A. I. (2016). SISTEM PAKAR PERJALANAN DINAS PEGAWAI NEGERI SIPIL PADA PEMERINTAH KOTA CIMAHI DENGAN METODE FORWARD CHAINING. Seminar Nasional Telekomunikasi dan Informatika, 56-61.

Mamase, S. (2016). Rancang Bangun Sistem Informasi Surat Perintah Perjalanan Dinas. 7-11.

Mulyati, S., \& Fajarita, L. (2018). PEMODELAN SISTEM INFORMASI PERJALANAN DINAS BERBASIS UML (UNIFIED MODELING LANGUAGE) PADA KEMENTERIAN ENERGI DAN SUMBER DAYA MINERAL SEKRETARIAT DIREKTORAT JENDERAL ENERGI BARU,TERBARUKAN DAN
KONSERVASI ENERGI. Jurnal Idealis, 126-131.

Muthia, N., Amalia, H., Puspita, A., \& Lestari, A. F. (2019). RANCANG BANGUN SISTEM INFORMASI AKUNTANSI PENJUALAN DENGAN MODEL WATERFALL BERBASIS JAVA DESKTOP. JURNAL ILMU PENGETAHUAN DAN KOMPUTER, 15-22.

Nurcahyo, W., \& Agustina, Y. (2012). PENGEMBANGAN SISTEM INFORMASI BERBASIS WEB MANAJEMEN PERJALANAN DINAS SATUAN KERJA PERANGKAT DAERAH (SKPD). JURNAL EKONOMI DAN BISNIS, 61-70.

Nurfarida, Amalia, H., \& Yunita. (2019). Laporan Penelitian Mandiri.

Prasetyaningrum, D. D., \& Juanita, S. (2018). RANCANGAN SISTEM INFORMASI PERJALANAN DINAS BERBASIS WEB STUDI KASUS: DIREKTORAT JENDERAL SUMBER DAYA DAN PERANGKAT POS DAN INFORMATIKA. jurnal Idealis, 218-223.

Rachmawati, S., Retnasari, T., \& Sunarto. (2018). Optimalisasi Sistem Informasi Perjalanan Dinas Dalam Meningkatkan Efisiensi Biaya Perusahaan. Jurnal Penelitian Teknik Informatika, 87-95.

Silvana, M., Fajrin, H., \& Danton. (2015). Analisis Proses Bisnis Sistem Pembuatan Surat Perintah Perjalanan Dinas Kantor Regional II PT.Pos Indonesia. TEKNOSI, 18-22. 